\title{
Bad Machinery and the Economics of Free Comics: A Webcomic Case Study
}

\author{
PADDY JOHNSTON, University of Sussex
}

\begin{abstract}
John Allison is one of a small number of alternative cartoonists in the UK today earning a living from their cartooning. However, since he began his first webcomic, Bobbins, in 1998, he has given all of his comics content away for free online. This article presents John Allison's comics, most notably his series Bad Machinery, as a case study of how to make free webcomics an economically viable labour, achieved by Allison's use of webcomics as a springboard for other commercial activities such as illustration work and printed comics. Taking an interdisciplinary approach consistent with the wider field of Comics Studies, this article draws upon concepts from sociology, literary criticism and economics to provide a theoretical framework through which to understand webcomics as labour, and thus to understand through this reading the economics of free webcomics, with John Allison as the exemplary web cartoonist.
\end{abstract}

\section{KEYWORDS}

Webcomics, John Allison, economics, crowdfunding, digital comics, content, cultural work, Foucault. 


\section{Introduction}

John Allison is one of the most prolific cartoonists working in the UK today, and was one of the first popular British webcomic artists. His first comic, Bobbins, debuted in September 1998, when webcomics had existed for at least five years, but were still a new and relatively undiscovered form of comic art. The Comics Journal's brief and cursory History of Webcomics (Garrity 2011) places this year in the midst of an explosion, with the 'online population' reaching a critical mass. Bobbins, appearing within this event, can be seen as a contributor to the establishment of the form as we now understand it: a popular format for comics online with daily, weekly or more sporadic updates. Allison has been drawing and posting around three to five pages of comics, often more, almost every week since he started in 1998.

Bobbins ran almost daily from 1998 to 2002. In that time John Allison's artwork went from a rough, MS Paint-inspired, somewhat crude style to a more refined, straightforward and clear line style, which after four years began to represent a unique voice and recognizable visual idiosyncrasy for Allison as an artist. Bobbins, like all of Allison's comics, was set in the fictional West Yorkshire town of Tackleford. The town continues to be the backdrop for an ongoing exercise in world-building that has continued throughout his different comics as he has developed as both an artist and a writer. The initial comic strip format of Bobbins, drawing upon the tropes of classic newspaper strips, lent itself well to the sitcom-esque feel which characterized it, with the characters developing in a similar fashion to a televised ensemble, eventually outgrowing the strip format and becoming more like a traditional newsstand comic book in its layout.

After he called time on Bobbins, Allison started work on a new comic called Scary Go Round (Allison 2002), which Garrity (2011) notes as one of the significant webcomic series of the mid-to-late 2000s, alongside PhD Comics, Girls With Slingshots, xkcd, Templar, AZ, Hark! A Vagrant, American Elf and Penny Arcade. The series retained some of the characters from Bobbins, most notably Shelley Winters, the protagonist of many of the storylines. As he did during the run of Bobbins, Allison experimented on various levels during the run of Scary Go Round, and tried various visual styles, tools and processes, varying his methods of production and distribution (though always distributing digitally in the first instance of each comic). He eventually settled on a recognisable clear-line, flat-coloured style, which he stuck to until 2009, when he stopped Scary Go Round and started his next series, Bad Machinery.

Scary Go Round departed from Bobbins by introducing light horror and mystery themes and leaning towards black comedy. Bad Machinery similarly departed from Scary Go Round by focusing on a group of teenagers, becoming less horror-focused and more wholesome, with light, fun mysteries aimed more at children and teens whilst still satisfying his existing adult readership. Bad Machinery has been his most commercially successful venture and US independent comics publisher Oni Press has been collecting Bad Machinery's web stories into physical books since 2012. At the time of writing, Allison has recently called time on Bad Machinery (Allison 2014a), has finished a two-issue spin-off titled Expecting To Fly (Allison 2014b), and has returned to Bobbins (which he has done off and on in recent years, between working on other projects).

Allison has been publishing comics for over fifteen years and every comic he has created has been posted page by page online in its initial form. While these are later collected into physical comic pamphlets and books, all Allison's comics remain free at the point of entry 
online. This means that he essentially gives away all of his content digitally, as do the majority of web cartoonists working today. His economic model is one that must therefore be examined on various levels in order to establish how comics can be conceived of as labour, both in this context and as part of a digital age in which content is easily distributed with little to no barriers of entry, financial or otherwise.

The inside back cover of the first issue of Allison's Scary Go Round spin-off comic Giant Days informs us in no uncertain terms that, despite giving all his content away for free as an initial digital offering, Allison does make a living from comics. This is often not the case for a lone cartoonist and it is a status which has significant impact on the conception of cartooning as labour and the cartoonist as a worker. The short creator biography reads:

John Allison is the creator of the comics Scary Go Round and Bad Machinery. Since 1998 he has essayed a series of stories, while making absolutely no attempt to deny that he "made them up." Perhaps it is this grotesque lack of shame that has allowed him to chisel out a living since 2003 doing just that (Allison 2013, 35).

This of course raises the question of how Allison makes a living from giving away his content digitally and the new economic models he exemplifies in this regard. The answer to this question, in the context of Comics Studies, can be found in an interdisciplinary reading of comics as labour and of the theoretical context of the ideas of Cultural Work and of the economic process of converting content into revenue.

\section{'Precarious conditions and uneven rewards:' Web cartooning as cultural work}

In December 2013 the comics studies website Comics Forum ran a series on Comics and Cultural Work, to which I contributed an article (Johnston 2013) that examined the portrayals of labour in the collaborative comic Conversation \#2, by autobiographical cartoonists Jeffrey Brown and James Kochalka. The comic depicts Brown and Kochalka complaining to each other about their respective day jobs and compulsions to create art, ending in an argument and resolution between the two avatars as they both celebrate their own abilities to create the comics they are compelled to create. The article concluded that Brown and Kochalka were positive about having a 'day job' to pay the bills as long as you can, in James Kochalka's words, find a job that 'doesn't want to make you vomit' (Brown \& Kochalka, 34). Both had to consider and overcome the economic and practical concerns of labour and the need for financial capital before they could become successful and effective cartoonists, whether this came through conceiving of their comics as work, or by separating them from capital entirely and providing for them with the capital acquired from an unrelated day job.

The preceding article in the series by Benjamin Woo (2013) drew on Adorno and Horkheimer's Dialectic of Enlightenment (Adorno \& Horkheimer 2002, 94-137) and asserted that it is difficult to conceive of comics as labour because the labour of cartoonists is obscured by the capitalist systems which surround them. When we do conceive of comics as labour, as a job, we find that while they are jobs with 'precarious conditions and uneven rewards,' (Woo 2013) they also come with autonomy. Autonomy is a significant concern for Cultural Workers and especially for alternative comics, a movement that grew historically from the underground comix movement's championing of freedom in the context of the perceived constraints of the Comics Code and the production-line process of mainstream comics. John Allison, as a consistent self-publisher and digital distributor, is granted a 
significant amount of freedom in comparison to many of his peers but this freedom is complicated by numerous other factors which surround his cartooning. Most notable of these is the need for a cartoonist to have numerous streams of revenue if they wish for their income from cartooning to become significant enough to provide a living, a state which may also be complicated by notions of freedom and autonomy in relation to their provision or lack thereof.

Freedom and autonomy are concepts which hold significant weight in the study of Cultural Work, which the Comics Forum series editor Casey Brienza provided a working definition of in her introduction to the series, drawing upon Howard Becker's seminal monograph Art Worlds (1982) and the media-focused sociological studies of Mark Banks, Rosalind Gill and Stephanie Taylor (2013). This working definition (Brienza 2013) states that anyone involved in cultural production can and should be understood as a Cultural Worker, but also acknowledges that strict delineations between Cultural Work and other types of work should not be made. Instead it can be useful to conceive of comics as work, cultural or otherwise, in order to advance our understanding of their production and distribution. However, the existing scholarship on Cultural Work provides further examinations of workers in the creative and cultural industries which are useful when conceiving of comics as work and examining them as such.

Media scholars David Hesmondhalgh and Sarah Baker cover Cultural Work extensively in their book Creative Labour (2011), and have also written about the working conditions of those engaged in the industries of television production, broadcasting and journalism, which like web cartooning are understood as Cultural Work. In a 2010 article for the interdisciplinary cultural studies journal Poetics, Hesmondhalgh and Baker survey a number of workers in the aforementioned industries, the vast majority of them freelance. Through the use of interviews and surveys they determine that the pay is low, the hours long and the terms of employment precarious and insecure across the board. However, they also find that autonomy is the trade-off, and they back this up by quoting fellow theorist of Cultural Work, Mark Banks. In his book The Politics of Cultural Work, Banks writes 'To be (or to appear to be) in control of one's destiny is what encourages workers to endorse the systems put in place to expedite flexible production' (Banks 2007, 55). This idea, in which relative autonomy and freedom in terms of the worker's own personal fulfilment are given precedence over financial and personal security and become the chief concern of the Cultural Worker, is one inherent in the conception of comics as work. It can also be seen as driving numerous decisions made in the production and distribution of comics and webcomics in particular.

Previous to the web, a cartoonist wishing to publish with autonomy and freedom (meaning publishing outside the corporate mainstream and often self-publishing) would have had to deal with significant costs of production and distribution associated with printed work. In webcomics the process of distribution from cartoonist to reader is a straightforward one, with no other parties involved or required other than perhaps the cartoonist's web hosting provider. This is of course an oversimplification, but it can enable us to acknowledge the autonomy and freedom offered by digital distribution. This is inherent in webcomics as a result of their being born digital, a product of the advances in technology made in the late 20 th and early $21^{\text {st }}$ centuries, which have provided a revolution across all media in terms of how 'content' is produced, distributed and consumed. As such we can understand webcomics as content, content as the product of Cultural Work, and cartooning as labour, as the Comics Forum series on Cultural Work did throughout. 
Returning to John Allison, the exemplary web cartoonist for the purposes of this article, understanding him as a Cultural Worker and his cartooning as labour immediately begs the question of how he is rewarded for this labour. This question takes on double significance in the context of the overview I have given of Alison's career, which follows the standard model for web cartoonists of giving away content for free in its initial digital format. The answer to this question is, unsurprisingly, a diverse, malleable and insecure combination of different streams of revenue; a combination of different sources of income for a freelance worker that offers, to reiterate Woo's phrase, 'precarious conditions and uneven rewards' (2013).

\section{Converting content into revenue: Crowdfunding, the curve and the economics of webcomics}

Comics' journalist and business professor Todd Allen has been writing on the subject of webcomics and their financial reward for some time. His 2007 book The Economics of Web Comics examines the income of a number of web cartoonists with data-driven analysis and commentary from web cartoonists themselves as well as from publishers and distributors. Since 2007 the technology surrounding webcomics has changed significantly. Most notable is the cost of bandwidth and hosting, which has become so nominal as to be insignificant, and the concept of micropayments. The idea of micropayments was that a minimal charge anything from one cent through to a dollar - could be made for a correspondingly small amount of content, such as a page of comics. More recently this concept has however been superseded by the prevalence of subscription and project-based crowdfunding. An updated edition of Allen's book has been funded recently with the help of a successful Kickstarter campaign; however, at the time of writing this edition is not commercially available. Briefly summarized, Allen's assessment is that content is converted into revenue through merchandising, advertising and other diversified streams of revenue, which he breaks down for various exemplary strips, including Penny Arcade (Holkins and Krahulik 1998), whose revenue streams are quoted thus:

- Advertising

- Merchandising (including their publishing efforts)

- Commissioned work (often specialty comic strips for other sites or games)

- Brand Consulting

- PAX - The Penny Arcade eXpo (Allen 2007, 95)

Penny Arcade is a popular strip, which largely comments humorously on video games and video game culture. It was one of the first webcomics to develop a highly successful model based on giving away content for free at the point of entry with this content directing consumers to other streams of revenue. Taking the same approach Allen takes above and using it to examine John Allison's works and publications, I have identified a series of streams of revenue which are similar to those listed above, whilst also tailored to his own comic and the content therein.

The first of these is advertising on his website. Without access to his site analytics it would be impossible to know his revenue from these, but with his significant readership there will be a regular payment from this, probably monthly or quarterly depending on the plan in place with Google or Project Wonderful, the two dominant providers of advertising on webcomic sites. 
The next is selling physical editions of his works - these are mostly collections of his online comics into comics pamphlets and books. Although specific sales data is here not available, Allison's online stores are often sold out of his various books, and his blog reveals that he has significant success with selling physical books and single-issue comics at conventions. Allen's analysis allows for the selling of physical editions to be seen as merchandising, a distinction which makes sense here in the understanding of Allison's revenue streams and his overall economic model.

Allison also produces a large amount of other merchandise, using his characters and his recognizable visual style to create fun and desirable products including prints, t-shirts, mugs, tote bags and tea towels. His merchandise is sold through US site TopatoCo and his UKbased store on BigCartel, through which he also sells custom artwork and commissions, which is a familiar strategy for cartoonists who pursue freelance illustration work in addition to creating comics.

Finally, Allison also offers users of his site the opportunity to 'subscribe' to Bad Machinery, i.e. to pay a small amount each year in return for being able to read his comics for free. This is an idea that has gained significant traction this year thanks to crowdfunding site Patreon, but Allison launched this in 2012, a full year before Patreon was founded. He received $£ 4,000$ worth of pledges within the first week, and wrote on his blog:

This will make a huge difference later this year when a glut of book work for the above collection will make it difficult to do commissions, freelance or prepare special items for conventions. It will buy me a two or three month holiday from near-constant anxiety (Allison 2012).

He has not blogged or tweeted about the subscription page since, and is clear about it having been an experiment, but it can still be acknowledged as a revenue stream and one which continues to gain traction online. The prominence of crowdfunding in the post-Facebook era is examined in Nicholas Lovell's book The Curve (2014a), a business-focused title similar to Todd Allen's book in its ultimate aim of advising creators of content on the best way to convert their content into revenue.

Lovell is a journalist and consultant, largely to the video games industry but also to others in the wake of his book, who advises companies and individuals on how to 'harness the transformative power of the internet' (Lovell 2014b). His essential argument is that the digital economy pushes the price of everything, even expensive luxury goods and essential commodities, towards being free, which has particular consequences for artists, writers and anyone who creates content. The Curve is a simple graph depicting revenue against consumption. Lovell proposes the theory that the majority of consumers of content given away will be, in his terminology, 'freeloaders,' who never pay, while the 'superfans' at the top of the graph will be responsible for the vast majority of money that a creator receives from selling his or her content. He suggests that all industries must adapt to giving away content for free, because this does in fact translate to sales in other associated areas of products, content or related services. This, as we have seen, is a part of John Allison's economic model and that of other content creators including Todd Allen, whose forthcoming reissue of his book on webcomics promises to address crowdfunding as a new and burgeoning stream of revenue (Alverson 2014). 
Crowdfunding has also been acknowledged as a significant revenue stream for cartoonists and a contributor to the rise of digital comics by prominent comics theorist Scott McCloud in conjunction with Henry Jenkins at a recent panel discussion (Jenkins 2014). The pair identified it as a facilitator of their shared vision of digital comics creating a diverse and vibrant landscape which benefits both producer and consumer in terms of their own freedom. In Jenkins' words as he assessed McCloud's 2000 treatise on digital comics, Reinventing Comics, this would be:

a world where independent comic artists sell their product directly to the consumer without confronting any middle men or gatekeepers, where more diverse comics content can find audiences well beyond the hard-core comics readers who rule the local comic shops, and where the formal vocabulary of comics can expand, freed from the limitations of the printed page (Jenkins 2002).

This vision is clearly based on freedom and autonomy, which as we have seen are significant concerns for the web cartoonist as a Cultural Worker, and crowdfunding has become a very important part of this vision as we see it realised today.

John Allison therefore makes his living like the majority of freelancers and the majority of Cultural Workers; from varied, piecemeal, disparate work and comparatively unreliable and precarious streams of income, in a state of constant anxiety. It is significant that even in the context of essentially being given $£ 4,000$ for free by his readership, he immediately places this in the context of the insecure nature of his work, which echoes Hesmondalgh and Baker's idea of 'a complicated version of freedom' (2010, 4). Allison is free to derive his income from his art and from its various associated streams of revenue, but this brings a level of complexity and insecurity not present in other conceptions of labour.

Allison has written about his work and these issues, as well as discussing these aspects of his work in numerous interviews, including one on the British comics podcast Make It Then Tell Everybody, hosted by cartoonist and comics educator Dan Berry. As well as light-hearted humorous discussion, the podcast's conversations discuss such issues as process, publishing, production and distribution. Allison has appeared as a guest on it twice, once in 2012 and once in 2014.

On the 2012 podcast Allison discussed how his making money from free content frustrated him, and its limitations. However, shortly after this conversation, Allison and Berry discussed autonomy and control, and both concurred that these factors were of the utmost importance to them as cartoonists working alone. Allison compared the cartoonist to a filmmaker, saying:

You're in charge [of telling the story]. You're the boss. It's like you're making a movie and you're in charge of everything. You're like the sound man. You're holding the boom. You're picking the shots. You can tell whatever story you want to. If you want you can produce the film. You own the cinema, if you want you can just sell it off your website. You can do it all. It's the ultimate egomaniac's format (Berry 2012).

This echoes the earlier ideas of the theorists of Cultural Work who assert the complication of the trade-off between autonomy and stability inherent in Cultural Work, and especially in comics when conceived of as work. 
Allison also posted 'a manifesto for indie comics' on his own blog in 2010, a post which was shared widely online and in the British comics community at the time of its publication. The post begins, 'Over the 12 years I've been active in UK indie comics, I've been constantly impressed by the standard of skill within our comics community, and horrified by the way people eventually disappear, unable to sustain themselves or their work' (Allison 2010). Again, this echoes the perilous nature of cartooning, and in fact takes this conception to its logical conclusion - ultimate submission to the peril created by cartooning, resulting in quitting cartooning altogether.

The ten-point manifesto continues in a similar vein, but gives instruction on how to combat this precariousness by seeing comics as work and as a business, and by being entrepreneurial. In other words by conceiving of comics as work, cultural or otherwise, and by working to convert content into revenue through all available streams. The most significant points in Alison's manifesto are numbers four and five:

\section{Forget what you learned at art school and read some business books}

You need entrepreneurial chops to make a living from your art, or the help of someone who has them. It's not that hard. You copy someone who has already succeeded. It usually works.

\section{Making money from art is not vulgar}

Art is a commodity. It makes people feel something. It raises the greater sum of human happiness. It increases the gaiety of the nation. It has a value (2010).

These points express the still somewhat controversial idea that making money from art is something you should do, and exemplify the entrepreneurial spirit which Allison upholds. It is this that allows him to make money from various sources, which facilitates his freedom in making his comics, despite this seemingly capitalist ethos being at odds with the anticapitalist sentiments of alternative comics that have developed during their history of opposition to the corporate mainstream. However, the changes to the landscape of comics facilitated by the growth of digital technologies have significantly complicated and eroded this opposition. Allison's ideas around the requirement of a cartoonist to be entrepreneurial are proof that webcomics and digital technologies have created new opportunities for cartoonists to gain revenue and to publish with creative freedom.

The implication in Allison's introduction to his manifesto is that where some of his peers have stopped cartooning, Allison has been able to continue because he has conceived of comics as work, of art as commerce and of himself as a businessman; a true and self-defined capitalist, self-facilitating his own production and distribution on his own terms and retaining the autonomy which is central to Cultural Work. It seems therefore that the key to dealing with the precarious nature of Cultural Work is to blur the boundary between Cultural Work and other types of work - to resist such delineations and to see cartooning as work and as a business within a wider entrepreneurial activity. Allison has managed to conceive of comics as work and to identify and exploit his potential revenue streams, and subsequently has been successful and effective as a cartoonist. His manifesto also suggests that he does not believe this to be a difficult thing to do. 


\section{Enterprise and production: John Allison as the homo oeconomicus}

Allison continued this thread of his personal philosophy in the aforementioned podcast interview.

You have to be everything. You have to be Barnum and Bailey. You have to be Marks and Spencer. You have to understand stock control and things like that. You have to understand so many different areas. And it's fun. There's a certain amount of risk. I'm quite risk averse, and when you print thousands of things it's expensive. And then what are you going to do, are you going to spend all that money when you make it back? You have to keep some of it so you can print your next book. And because I was cautious I was able to continue. Because I was cautious I was able to take these risks at a comfortable level and to keep going. I've made mistakes along the way, but thankfully they didn't take me out (Berry 2012).

Allison here emphasizes the individual effort of the web cartoonist and implies, in suggesting that a cartoonist must be 'Marks and Spencer', that to succeed a lone cartoonist must become a one-person corporation (an organization, in the cultural and creative industries, made up of numerous Cultural Workers). In effect one cartoonist must do the work of numerous people to be a successful cartoonist, a similar model to the successful corporate mainstream in which many Cultural Workers divide the labour required to create a comic. Thus they produce a comic with relative ease, while their counterparts in the alternative comics sphere, particularly web cartoonists whose comics are free at the point of entry, fail.

The model of Cultural Worker suggested here by Allison is one which echoes, in no short measure, the idea of the homo oeconomicus established by Michel Foucault in his 1978-9 series of lectures, The Birth of Biopolitics (2008). Foucault, as a cultural and social theorist, is prescient here for a number of reasons including a growing reassessment of his ideas in the context of digital culture. In a broad sense, Foucault's work has had a significant influence on literary criticism, from which comics studies still draws many of its basic ideas. Foucault is also being granted renewed attention by scholars of various disciplines at present, due in part to the recent posthumous publication of works previously denied publication by his literary estate, and in part due to his work on neoliberalism. This is a topic that has come under renewed scrutiny and prominence in light of global politics since the economic crash of the late noughties and the subsequent political landscape, which many scholars argue has seen a renewed neoliberal consensus. A recent conference keynoted by Judith Butler at Yale, Foucault after 1984, confirmed this, with a write-up in the LA Review of Books reiterating Foucault's exposition of the neoliberal ideology in which 'the things that would seem most incommensurate with economic rationality... are judged increasingly by economic standards' (Morrow, Racugglia \& Schectman 2014). The example given in the conference review is that of the neoliberal university, but it echoes Allison's earlier grapple with the idea that 'Making money from art is not vulgar' (Allison 2010). For Allison, it is perfectly acceptable to judge art as a commodity, commensurate with the neoliberal consensus.

Foucault's homo oeconomicus is defined in The Birth of Biopolitics as 'not the man of exchange or man the consumer; he is the man of enterprise and production' (Foucault 2008, 147), and explained thus:

Homo oeconomicus is an entrepreneur, an entrepreneur of himself. This is true to the extent that, in practice, the stake in all neo-liberal analyses is the replacement every 
time of homo oeconomicus as entrepreneur of himself, being for himself his own capital, being for himself his own producer, being for himself the source of [his] earnings (226).

At the same time he is also 'an island of rationality' (282) and 'someone who accepts reality' (270). The use of the term entrepreneur is one which is used in the same way by John Allison in his manifesto for indie comics, suggesting the successful cartoonist should treat himself as an entrepreneur. Similarly, his manifesto accepts reality and presents a truly rational assessment of the web cartoonist, encouraging rational behaviour and acknowledgment of the economic conditions of producing and consuming art, all the while viewing the cartoonist as a figure operating alone - Barnum and Bailey; Marks and Spencer; the one-man corporation.

Allison's suggestion, empirical as it is, that he has seen many of his peers fail at cartooning because of their refusal or inability to engage with this conception of cartooning as work and of the cartoonist as a rational, economic man, is proof of his status as a true and realised homo oeconomicus. He rationally exploits the opportunities offered by technological change and digital culture, specifically webcomics and the associated economic model of converting digital content into revenue through content-related merchandising. Allison's own success as a cartoonist, one who earns a living through giving away his content for free, is also proof of this. He may not explicitly or consciously think in these terms, but he undoubtedly provides a contemporary example of Foucault's economic man, which is an analysis it is possible to present here without endorsing the ideology of neoliberalism and without reducing a work of comic art to nothing beyond a commodity. Allison's comics have developed through various visual approaches to arrive at a unique, distinctive clear line style and become elegantly written stories with a significant and enthusiastic readership. Through this Foucauldian reading I wish to demonstrate that these significant aesthetic developments in Allison's comics would not have been possible without the facilitation of his economic activity as it engaged with digital culture, the exposition of which allows for a new understanding of his prolific nature and thus the narrative structure of his works.

John Allison's work in comics and his own commentary on the subject allow for a conception of comics as Cultural Work and offers insights into the working conditions of web cartoonists through this conception. They allow for an understanding of web cartooning as an economic endeavour, as well as presenting a model for success in the sphere of webcomics in financial terms. However, Allison's financial success is also indicative of his success in creating, growing and maintaining a large and responsive readership, all of which has been facilitated by the changes in technology that have allowed digital comics and webcomics to flourish and become a vibrant art form in their own right. Allison is of course just one example of a successful web cartoonist, but one against which others can be measured. His status as a homo oeconomicus, as well as his facilitation of a reading of comics as Cultural Work and the breakdown of revenue streams offered in this article, are all ideas which can be applied to other web cartoonists. I hope that this case study will provide a springboard for others to assess webcomics in a similar fashion and to understand them as work, and their creators as workers and entrepreneurs. This is an understanding from which we can begin to draw a vision of the myriad factors which underpin the creation of a comic, digital or in print, and thus to understand comics themselves in greater depth. 


\section{References}

Adorno, T. \& Horkheimer, M. (2002) The Dialectic of Enlightenment, Stanford: Stanford University Press.

Allen, T. (2007) The Economics of Webcomics: A Study in Converting Content into Revenue, $2^{\text {nd }}$ Edition, New York: Indignant Media.

Allison, J. (1998) Bobbins, [online]. Available at: http://www.scarygoround.com/bobbins/index-archive.php?date=archive. Accessed 17 March 2015.

Allison, J. (2002) Scary Go Round, [online]. Available at: http://scarygoround.com/sgr. Accessed 17 March 2015.

Allison, J. (2009) Bad Machinery, [online]. Available at: http://scarygoround.com/ar.php. Accessed 17 March 2015.

Allison, J. (2010) 'A Scene That Celebrates Itself Has Nothing to Celebrate', [online], 18 November 2010. Available at: http://sgrblog.blogspot.co.uk/2010/11/scene-thatcelebrates-itself-has.html. Accessed 16 November 2014.

Allison, J. (2012) 'The Subscription Experiment', [online], 20 February 2012. Available at: http://sgrblog.blogspot.co.uk/2012/02/subscription-experiment.html. Accessed 16 November 2014.

Allison, J. (2013) Giant Days \#2, Oldham: self-published.

Allison, J. (2014a) 'Goodbye, Bad Machinery', [online], 3 November 2014. Available at: http://sgrblog.blogspot.co.uk/2014/11/goodbye-bad-machinery.html. Accessed 16 November 2014.

Allison, J. (2014b) Expecting to Fly, Oldham: self-published.

Alverson, B. (2014) 'Todd Allen on his "Economics of Digital Comics" Kickstarter', [online], 3 July 2014. Available at:

http://robot6.comicbookresources.com/2014/07/todd-allen-on-his-economics-ofdigital-comics-kickstarter/. Accessed 16 November 2014.

Banks, M., Gill, R. \& Taylor, S. eds. (2013) Theorizing Cultural Work: Labour, Continuity and Change in the Cultural and Creative Industries, London: Routledge.

Banks, M. (2007) The Politics of Cultural Work, London: Palgrave.

Berry, D. (2012) 'John Allison', Make It Then Tell Everybody, [audio podcast], 9 November 2012. Available at: http://makeitthentelleverybody.com/2012/11/john-allison/. Accessed 16 November 2014.

Berry, D. (2014) 'John Allison', Make It Then Tell Everybody, [audio podcast], 20 March 2014. Available at: http://makeitthentelleverybody.com/2014/03/john-allison-2/. Accessed 17 March 2015.

Brienza, C. (2013) 'Comics and Cultural Work: Introduction by Casey Brienza', [online], 2 December 2013. Available at: http://comicsforum.org/2013/12/02/comics-andcultural-work-introduction-by-casey-brienza/. Accessed 16 November 2014.

Becker, H. (1982) Art Worlds, Berkeley: University of California Press.

Brown, J. \& Kochalka, J. (2005) Conversation \#2, Marietta: Top Shelf Comics.

Foucault, M. (2008) The Birth of Biopolitics, London: Palgrave.

Garrity, S. (2011) 'The History of Webcomics', [online], 15 July 2011. Available at: http://www.tcj.com/the-history-of-webcomics/. Accessed 16 November 2014.

Hesmondhalgh, D. \& Baker, S. (2011) Creative Labour: Media Work in Three Cultural Industries, London: Routledge.

Hesmondhalgh, D. \& Baker, S. (2010) 'A very complicated version of freedom', Poetics: Journal of Empirical Research on Culture, the Media and the Arts, 38(1), 4-20 
Holkins, J. \& Krahulik, M. (1998) Penny Arcade, [online]. Available at: http://www.pennyarcade.com/archive. Accessed 17 March 2015.

Jenkins, H. (2014) 'Scott McCloud Reimagines The Future of Comics', [online]. Available at: http://henryjenkins.org/2014/11/scott-mccloud-reimagines-the-future-ofcomics.html. Accessed 16 November 2014.

Jenkins, H. (2002) 'Will The Web Save Comics?', [online]. Available at: http://www.technologyreview.com/news/401445/will-the-web-save-comics/. Accessed 16 November 2014.

Johnston, P. (2013) 'Comics and the Day Job: Cartooning and Work in Jeffrey Brown and James Kochalka's Conversation \#2', [online]. Available at: http://comicsforum.org/2013/12/17/comics-and-the-day-job-cartooning-and-work-injeffrey-brown-and-james-kochalkas-conversation-2-by-paddy-johnston/. Accessed 16 November 2014.

Lovell, N. (2014a) The Curve: Turning Followers Into Superfans, London: Penguin.

Lovell, N. (2014b) 'The Curve Online', [online]. Available at: http://www.thecurveonline.com/. Accessed 16 November 2014.

McCloud, S. (2007) Reinventing Comics. London: HarperPerennial.

Morrow, S., Raccuglia, P. \& Shechtman, A. (2014) 'Foucault's Risks', [online], 7 November 2014. Available at: http://lareviewofbooks.org/essay/foucaults-risks/. Accessed 16 November 2014.

Woo, B. (2013) 'Why is it so hard to think about comics as labour?', [online], 9 December 2013. Available at: http://ComicsForum.org/2013/12/09/why-is-it-so-hard-to-thinkabout-comics-as-labour-by-benjamin-woo/. Accessed 16 November 2014.

Paddy Johnston is a Doctoral Researcher in the Department of English at the University of Sussex, currently researching comics as labour and focusing on cartoonists working alone in alternative comics. His other research interests include cultural work, authorship, crowdfunding, neoliberalism and political economy. He writes about comics for The Comics Grid, Comics Forum and Graphixia, and is a cartoonist, musician and podcaster, as well as working in publishing.

Email: p.johnston@sussex.ac.uk

Twitter: @paddyjohnston 